\title{
A wedding party, something old, something new: The history of the formation of the British-Sikh regiments
}

\author{
Kamalroop Singh ${ }^{1}$
}

\begin{abstract}
Although previously opposed to each other, the wedding party of the British and the Sikhs met after the dramatic fall of the Sikh Empire and death of the legendary Maharaja, Ranjit Singh. The stalwart Sikhs made the conquest of the Punjab very difficult and it was the final Indian jewel in the crown of Queen Victoria. After the fall, the British recognised that the Sikhs were experienced warriors and that they would protect the British-India border from the Afghans, so they began recruiting Sikhs in their army in large numbers. In this paper I will explore how the formidable British-Sikh regiments were formed, and how they later went on to participate in the theatres of World War I, and highlight their notable achievements. Sikh warrior or chattrī ideals, celebrate both martial arts and battle warfare, and praises martyrdom and heroism. This is seen in the Sikh scriptural and bardic

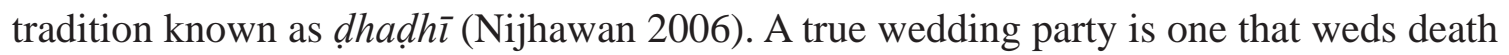
and looks at fear with disdain. This tradition of 'playing the game of love' has been noted by a number of scholars (Fenech 2000).
\end{abstract}

As the title suggests, the purpose of this article is to illustrate how British-Sikh regiments were formed. A unique example of this is how the martial Sikhs, or the Akalis, were utilised by the British according to the martial races theory. The interaction of Sikhs with Europeans transformed their outlook and practices. ${ }^{2}$ This article begins with a brief history of the Gurus, followed by an overview of the relationship of the British and Sikhs before World War I. The Sikh regiments of both Maharaja Ranjit Singh and the British have received much scholarly attention, but there has been little analysis of the contribution of the Akalis. While scholars have examined the Martial Races theory (Omissi 1991), the Sikh Regiments, and have looked at the history of the Anglo-Sikhs wars (Sidhu 2014), there has been very little examination of how this Sikh warrior ethos actually came to be. Although, this tradition of "playing the game of love" or martyrdom has been noted by a number of scholars (Fenech 2000 and Nijhawan 2006), it has not been examined $a b$ origine, which is from within the Sikh military order or the Akali Nihangs. ${ }^{3}$

1 The author of this paper is a Sikh, and my paternal grandfather served in Burma in the BritishIndian Army in the Second World War, and was decorated, but I am unsure if my forefathers served in the First World war.

2 Many soldiers from the Sikh regiments went on to found the Singh Sabha, a reformist movement of the Sikhs.

3 They are also known as Akalis, Nihangs, Nihang Singhs or Akali Nihangs. 
The Sikh Dharma began with Guru Nanak (1469-1539) and continued with nine successive human Gurus. ${ }^{4}$ The Guru stressed meditation on God's name, hard work, and to share ones earnings. After the martyrdom of the Fifth Guru (1563-1606), this would become a tradition amongst the Sikh Panth or community. After this, martial concepts where institutionalised by his son, who was the Sixth Guru (1595-1644), he donned two swords (miri-piri) to symbolise both pietism and heroism. He installed weapons which were to be worshipped in a new military and political throne called the Akal Takht Sahib, where bards sang the songs of valour (Nijhawan 2006: 54-7). This new spirit of sacrifice was based on devotional verses like:

If you wish to play the game of love.

Then come with your head in the palm of your hand.

Jao tao prem khelan kā chāo.

Sir dhar talì galì merī ào.

(Adi Sri Guru Granth Sahib, p. 1412).

Guru Nanak stressed that God was one, thus his onto-theology was non-dualitistic, therefore as death is a part of the Divine it is also to be embraced:

Death would not be called bad, O people, if one knew how to truly die.2.The death of brave heroes is blessed, if it is approved by God.

(Adi Sri Guru Granth Sahib, p. 579)

The fifteenth century saint Kabir sums up this sentiment as:

Kabir, the world is afraid of death - that death fills my mind with bliss. It is only by death that perfect, supreme bliss is obtained. ${ }^{22}$

One interpretation of this and other verses is that sacrificing oneself for the greater good, is to be in accordance with God's will or the hukam. The Gurus and other martyrs are often portrayed as welcoming their torture in the same way as they would pleasure, with complete equanimity. This stoicism sounds superhuman but as we shall see it was demonstrated regularly by the Sikhs in the battlefields of World War One.

After the martyrdom of the Ninth Guru (1621-1675), and due to the ever increasing persecution by the Moghuls and their allies, the Tenth Guru, Guru Gobind Singh (16661708), organised his followers into a military confederation called the Khalsa (1699). Keeping the aforementioned spirit of sacrifice alive, Guru Gobind Singh requested five heads when he inaugurated the Khalsa, and the new initiation would be by the doubleedged sword or khanda. The Khalsa had a new uniform or bana consisting of the $5 \mathrm{~K}$ 's which have both spiritual and military meaning. These are the kesh, kanga, kirpan, kara, and keshera - the unshorn hair, wooden comb, sword, steel wrist bangle; and loose, long, cotton boxer shorts tied with a cord. The battled hardened warriors known as the Akalis from the Sixth Gurus reign who were ascetic itinerants, now became the elite 4 Dharma can be loosely translated to mean religion, but a more precise meaning is the good or noble path, or the righteous path 
corps of the Khalsa. As they had more experience and served longer, they became Generals, and were known as the Akali Nihang Singhs, with their higher rank characterised by their farla or miniature battle standard on their turban, which was commenced by the Tenth Guru. ${ }^{5}$

The main leitmotiv in the scripture of the Tenth Guru, known as the Sri Dasam Granth Sahib, is righteous war or Dharma Yudh. Within it Death is synonymous with God, under the names of Mahakal - The Great Time or Death, and Sarbkal - as the All Death. However, violence is considered a last resort, viable only after all other means have been exhausted (Zafaranamah, Sri Dasam Granth Sahib: 1389-90, verse 22; Bhogal 2007: 102). The Tenth Guru compares the warriors to brides undergoing wedding customs before their marriage to death:

bir kangane bandhin aru achharain sir telu.

In order to wed [death], the warriors put on bracelets, and anoint their heads with oil.

(Sri Dasam Granth Sahib, p. 243)

The marriage party would dress in red,

Swords in hand, the warriors of both sides fought on the battlefield. Having been chopped into pieces, they fell, but still they did not turn back. On being wounded, it increased their fervour, and they appeared like the members of the marriage party walking in their [red] dress.10...Saturated with blood the warriors appeared like a marriage party wearing red garments.86. (Suraj Avatar, Sri Dasam Granth Sahib, verses 10, 86.)

Therefore, the army was considered a wedding party ready to wed death, with their blood stained garments. The chivalrous code they were to follow would be called the rahit maryada, which literally means to "live whilst remembering death". In the early records of the rahit there are injunctions to practice martial arts daily - shastravidia da abhias (Bhai Daya Singh Rahitnama, circa early eighteenth century). ${ }^{6}$ In the Prem Sumarag Granth from around 1700 AD, which was written in the Court of the Tenth, there are chapters on conduct, rites of life, and political affairs of Kings, in which the author considers the military profession to be a noble service:

He who enters service should do so as a soldier. How should he serve? He should do so fearlessly; and he should be content with his monthly wages [rather than seeking his rewards in looting].8. If, while in service he is sent anywhere to fight he should understand what he is meant to do and should prove himself a hero.9. While engaged in warfare, he should never loot. He should never seek to possess another's property. 10. He should do whatever his commander orders.11.6 (McLeod 2006: 67).

With a newly trained army in place, the Guru established the fortresses of Anandpur Sahib, as he prepared to meet the delegated forces of the Moghals on the battlefield. In

5 The ethos is simple it is better that the soldiers die rather than the Khalsa Battle Standard dropping to the ground or being taken by the enemy. The farla was also worn in British regiments. Bhai Svarup Singh Kaushish, Guru Kian Sakhian, 1790, ed. Padam \& Garja Singh 1986: 136.

6 See my chapter on the history and practice of the Sikh martial art; K. Singh 2014. 
1708, after the lineage of human Gurus, the Guruship passed to the teachings which are found in the scripture titled the Adi Sri Guru Granth Sahib, which is revered by the community of students or disciples (Sikhs), known as the Sri Guru Panth Sahib.

Simultaneously, on the banks of the Hugli oppression it was similarly converting the peaceful trader into the spirited soldier. Admiral Nicholson was preparing to commence war with the Subedar (equivalent to a British Captain) of Bengal. The founder of 'modern' Calcutta, Job Charnock, was hastily constructing entrenchments at Hijli in West Bengal to receive the British settlers and their property. In 1784, Governor-General Warren Hastings placed a British agent at the court of Delhi in order to monitor the Sikhs. This was to prevent them from making any attempt upon the kingdom of Oude or Awadh (1732-1858), but it proved to be futile as the British still had to face the Sikhs in battle only a few years later (Humbly 1854: 61).

In 1798 the mercenary George Thomas marched with his forces to Karnal, where a body of Sikhs had gathered in rebellion against the Maratha rule in Saharanpur. Four successive battles were fought and both sides sustained heavy casualties (Francklin 1805: 113). These engagements would lead to the chief political agent, Lieutenant-Colonel Sir John Malcolm, to visit the Punjab in 1805, and for him to publish his findings in the Sketch of the Sikhs in 1812. He notes the military traditions of the Sikhs and that the martial Akalis had the supreme traditional authority in the Sikh Temples and that they led the annual 'National Assembly' (Malcolm 1812: 52, 89, 107, 115, 120, 122, 123, 136).

The Sikh states of Patiala, Jind, Nabha, Faridkot and Kaital - all branches of the Phulkian misl or confederacies, became allied to the British in 1803. ${ }^{7}$ The policy of the British was to strengthen the boundary by sustaining and protecting the different independent chiefs along its frontier, carefully providing that with separate and rival interests, "they should be so divided as to render combination impossible" (Browne 1861: 183).

Maharaja Ranjit Singh then began to employ some of the specialist Akalis or Nihang Singhs to expand his empire, and enlisted them as his own elite irregular cavalry known as the goracharra khas. In 1805, when the Maratha ruler Holkar had come to Punjab pursued by the British, Maharaja Ranjit Singh had anticipated a war with the British. After Holkar left, Ranjit Singh visited Lord Lake's camp in disguise to find that British troops were better trained than Holkar's (Moorcroft \& Trebeck 1841: 102). Therefore, he resolved to prepare an equivalent army so as to meet any future encounter with the British. A national army, which up till then was unknown in the sub-continent, rather than being dependent on the feudal system of the chiefs, became the policy of the Maharaja. This was the beginning of "something old and something new" for the Sikh armies.

The head of the Akalis, Phula Singh, had regular skirmishes with British troops, which reached its crescendo with Sir Charles Metcalfe's escort in 1808. According to Smyth (1847), Akali Phula Singh wanted to slaughter Metcalfe for the Shi'a procession of Mu-

7 Phulkian as in descended from a common ancestor named Phul; see the Calcutta Review, Vol. LXXIX (1884): 390-1. 


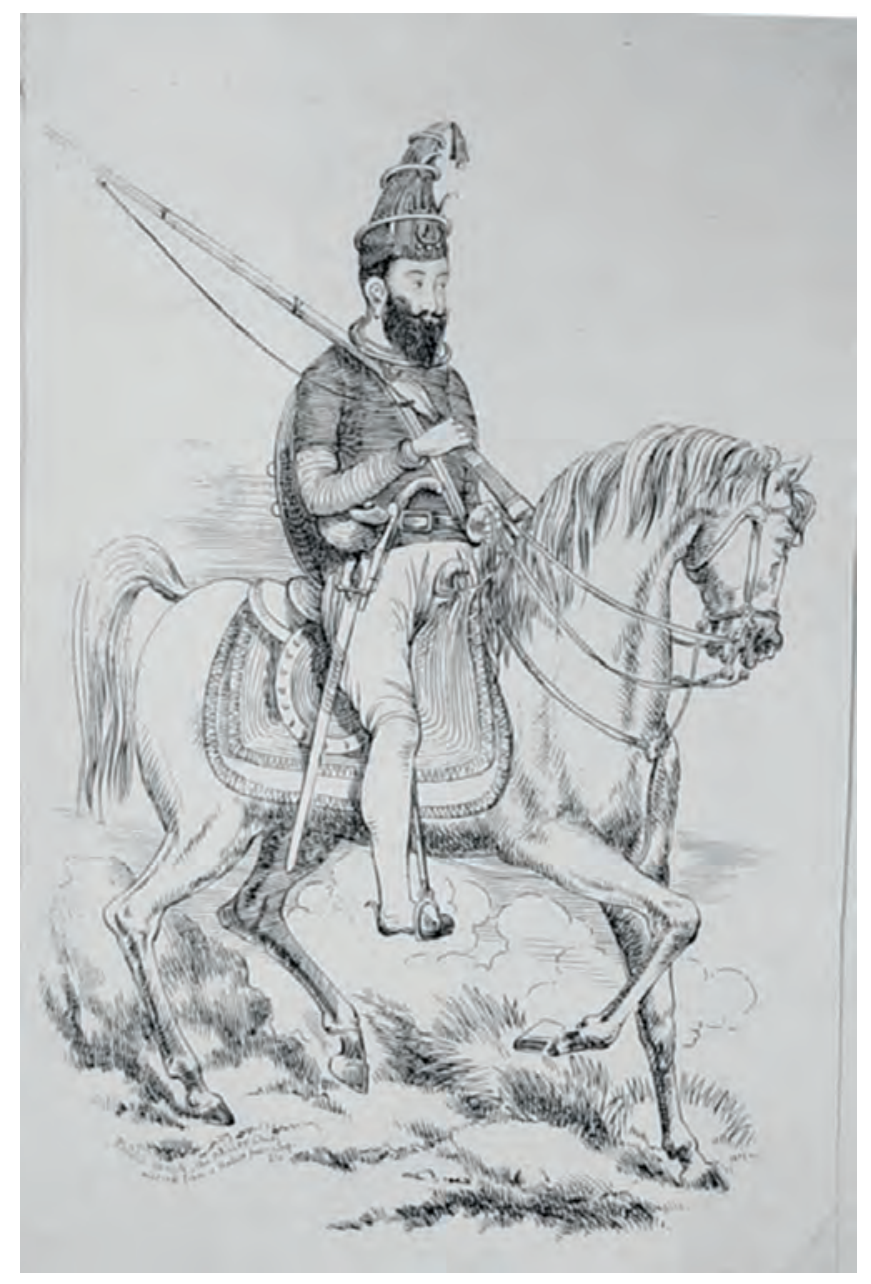

Image 1. 'Portrait of Akali Phoola Singh' (British Museum: As2006, Prt.336.), sitting on a horse wearing a 'fortress turban' (dastaar boonga) with metal quoits and weapons attached; he carries a sword and dagger tucked into his robes, and carries a gun over his right shoulder. Lithograph, circa 1839-1846. Reproduced by permission of the artist. (C) The Trustees of the British Museum.

harram in Amritsar. ${ }^{8}$ The efficiency of the British troops of Metcalfe against the Akalis who outnumbered them, gave Ranjit Singh the impetus to modernise his army, as he was eye witness to the skirmish. "Having thus learned the value of discipline, he was seized with the desire to possess and disciplined army” for his purposes. ${ }^{9}$ Cunningham (1849) also narrates that another incident took place around this period, against an officer surveying or making a map of the states (Cunningham 1846: 165). This incident is narrated in detail by Giani Gian Singh (1892) in his Twarikh Guru Khalsa. He explains that in 1810, Akali Phula Singh had an argument with Wight Sahib and killed six of his men and injured twenty of them (Giani Gian Singh 1892, II: 50).

The Maharaja employed the Akalis in many battles and many were won due to their daring attacks and bravery, for example the battle of Multan in 1818 and the capture of Kashmir in 1819 (Smyth 1847: 188). In 1825 a Persian account of the Sikhs by Colonel James Skinner, records some of these chattri or military traditions of the Akalis. ${ }^{10} \mathrm{He}$ notes that they ate jhatka meat - which is decapitated with one blow by a sword, and that most of them wear blue turbans and a kachchha (keshera). Skinner states:

8 Muslim Shi'a festival commemorating the martyrdom of Iman Hussain. Smyth 1847: $20-2$.

9 Ibid. p. 22. This is also mentioned by Metcalfe himself, see Kaye: 1854: 304.

10 See my aforementioned chapter on Sikh martial arts in The Handbook of Sikh Studies, 2014. 
All follow the profession of soldiery and are brave, being without peer in the art of musketry and mobile warfare (chakkar-bazi). The Akali sect is particularly courageous and warlike. ${ }^{11}$

By 1830 the Maharaja began to modernise his Sikh Regiments, who were trained in the European model of warfare, with the help of his European generals. One of Maharaja Ranjit Singh's famous regiments was the Fauj-i-Khas, which was a brigade of the Fauj-i-ain or his the regular army, it had four battalions of infantry and two regiments of cavalry and a troop of artillery. The cavalry was built on a British model and the infantry on French patterns, and commanded by French officers. He employed generals from Europe such as Allard, Court, Ventura, and Avitabile, who were veterans from the wars

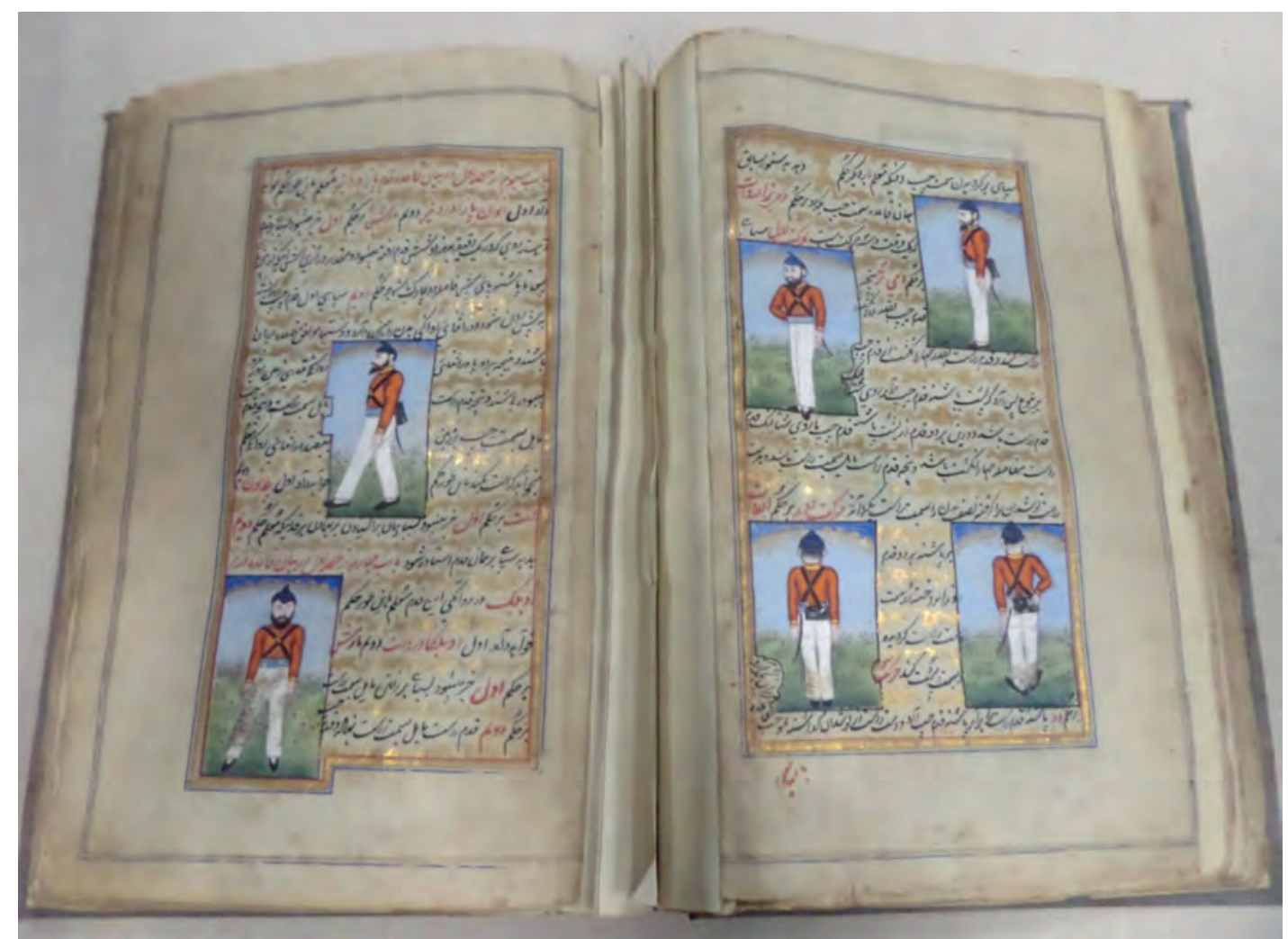

Image 2. Persian military manual written for the Fauj-i-Khas. This is on display at the Maharaja Ranjit Singh Museum, Amritsar, circa. 1830s.

of Napoleon. The European officers could speak and write Persian, and their very detailed knowledge of the language is clear from the military manual written by them. It was written for the Fauj-i-Khas of Maharaja Ranjit Singh, and has three different sections for drills, weapons training, and marching. Barr notes that,

...the more closely-fitting dress of an officer belonging to one of the Maharajah's regiments pointed out that European customs had been adopted to some extent, but the exis-

11 J. Skinner, “The Sikh Community”, 1825. From the Persian, Kitab-ī Tashrīhu'l Aqwām (History of the origin and distinguishing marks of the different communities of India), trans. Shireen Moosvi. See, British library, Add. 2755, ff 159-160b. 
ting head-dress of crimson or other bright coloured silk still attests the unwillingness of the Sikh soldier to wear the chako...(Barr 1844: 112).

As can be noted by the uniforms of the soldiers in the manuscript, the blue uniform or bana of the Guru was abandoned, consequently the Akali Nihangs became an elite religious corps, who were outnumbered but revered by the other regiments. By reducing the number of Akalis, and limiting their role in the regiments, this allowed the Maharaja to stop the Sarbatt Khalsa or Khalsa National Assembly, thus making him the supreme ruler. According to Cunningham,

It has been usual to attribute the superiority of the Sikh army to the labours of these two officers and of their subsequent coadjutors, the generals Court and Avitable, but in truth, the Sikh owes his excellence as a soldier to his own hardihood of character, to that spirit of adaptation which distinguishes every new people and to that feeling of a common interest and destiny implanted in him by his great teachers [Gurus] (Cuningham 1846: 173).

The Maharaja was very impressed by the performance of the Fauj-i-Khas, so he ordered a total reorganisation of his army of this European model in 1835. This alarmed the British, who had come to see the emerging military power of Punjab as a threat, to such a degree that in 1837 they issued orders "to be vigilant and try to arrest any French officer travelling in disguise to join Ranjit Singh's army” (Lafont 1986: 18).

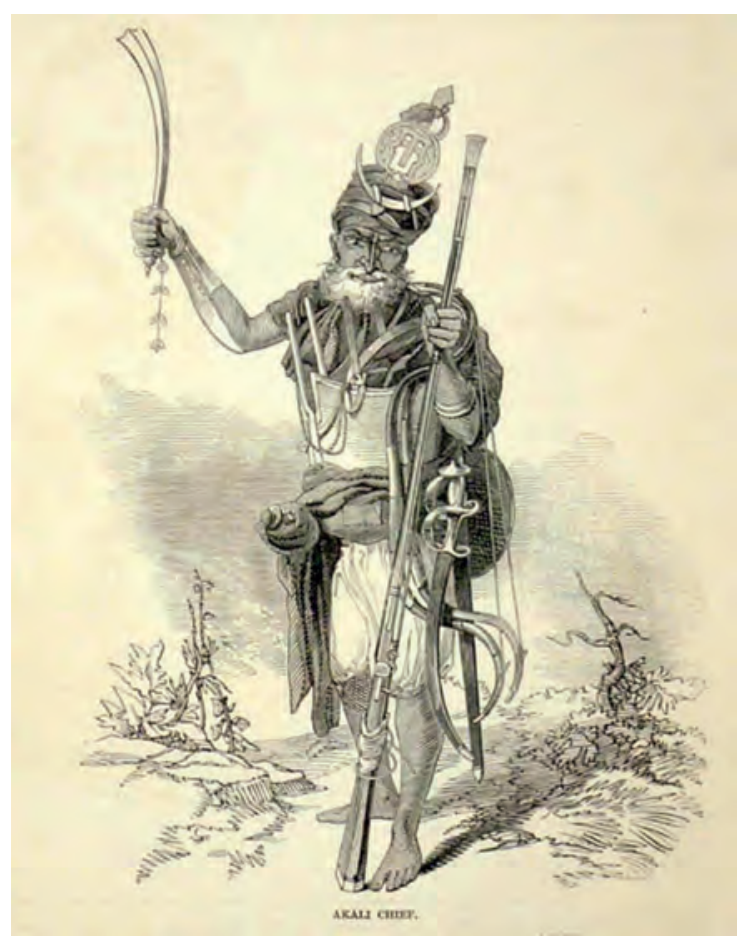

Image 3. A wood engraving of an 'Akali Chief' by G. T. Vigne, circa 1846. This is likely to be Akali Sat Hanuman Singh Nihang. dom or Sarkar-i-Khalsa, Akali Phula Singh went into battle with 12,000 men, however due to the superior positions of the Afghans many hundred Akalis were slain in battle (Vigne 1842: 255). Akali Phula Singh also fell in battle, but gave a narrow victory to the Maharaja (Prinsep 1834: 138-9). His leadership was succeeded by Akali Sat Hanuman Singh. His loss was mourned by the Sikh nation, and by the Maharaja who organised his last rites and built his memorial himself.

By the time of his death (1839), Maharaja Ranjit Singh had formed a magnificent army in Asia second to the British. Due to his intelligence sources, the Maharaja was well aware of the military power of the British, and therefore during his lifetime he remained 


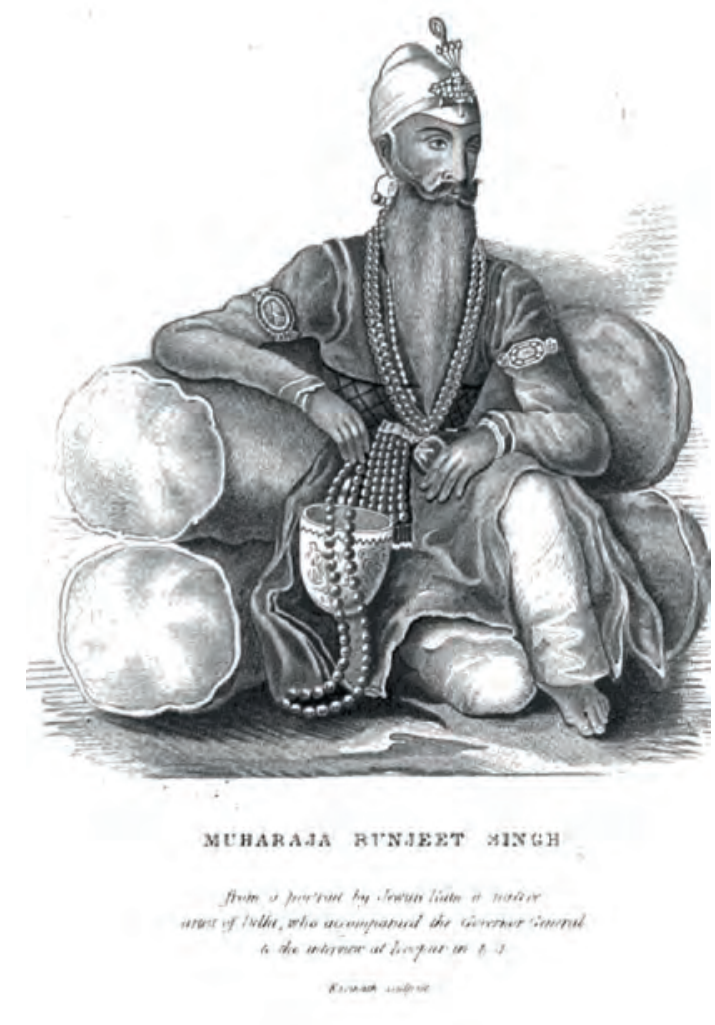

Image 4 (left). Maharaja Ranjit Singh, circa 1834. A wood engraving of an 'Akali Chief' by G. T. Vigne. Image 5 (opposite page). 'Battle of Mudki' by Henry Martens, 1849.

a strong ally, and adjusted his own forces accordingly. He tried his best to consolidate the traditions of the past, while upgrading to new modern warfare techniques of the time.

\section{The Akalis forge an alliance with the British against the Afghans}

The British having themselves been on the receiving end of the Akalis, would now utilise them to protect their own interests. Maharaja Sher Singh, the heir of Ranjit Singh, was approached by the British to be an ally against the Afghans in 1839. This led to the Maharaja, and an Akali regiment of around five hundred Nihang Singhs, with another 4,500 men of mostly Punjabi Muslims, going on a new allied campaign to the Khyber Pass. The famous hit and run tactics of the Akalis were noted by the military man, Lieut. W. Barr, who was present on the battlefield:

...what he said is the favourite manoeuvre of Seikh horsemen, and that it is the custom of their troops to advance and retreat, rally and return to the fight - and a most useful manoeuvre it is, as well knew the great Frederick, who desired to have the men "that could run and rally.”[sic $]^{12}$

This was widely published in military journals of the time, which led to the strategy of utilising the Sikhs for British purposes. A 'Sikh patriot' suggested to the British administration of the Punjab that "the Sikh States should be required to keep establishment

12 "Journal of a march from Delhi to Peshawur, and from thence to Cabool with the Mission of Colonel Wade, including Travels in the Punjab, a visit to the City of Lahore, and a narrative of Operations in the Khybur Pass in 1839”, by Lieut. W. Barr: post 8vo. cloth, with six illustrations.'; Calcutta Review, Vol. 2, Calcutta: Sanders and Cones, 1844: 163, 183. 


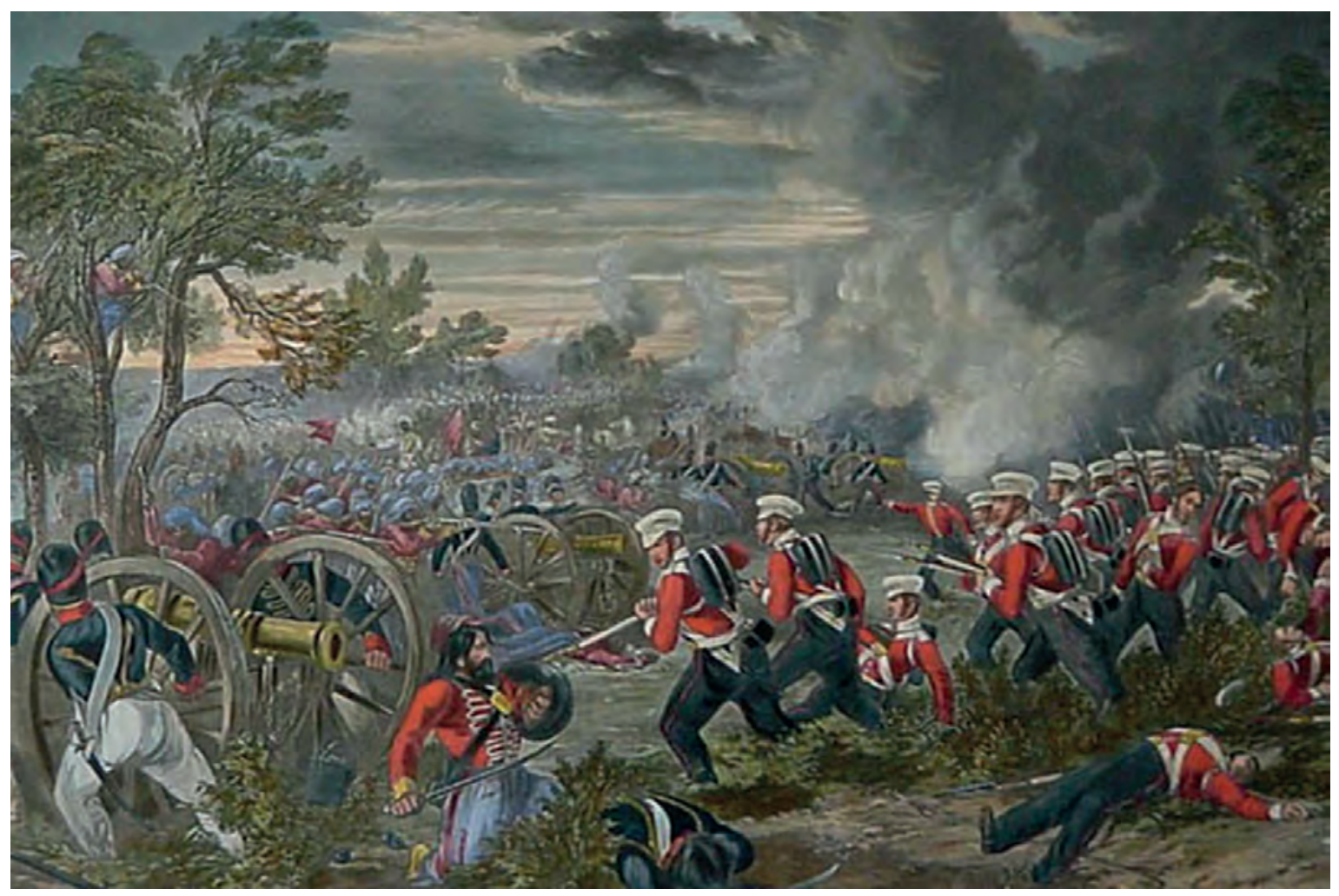

of Nihangs for service in war in time of need”. He proposed this to a late LieutenantGovernor, Punjab, to raise two regiments (foot and horse) of the Nihangs and to position them at some difficult places; but they would not like to come under regular service, nor would they like to be called to retreat when once ordered for attack, however dangerous it be. ${ }^{13}$

\section{The Anglo-Sikh Wars}

In 1845 taking note of the worsening situation with the British, Akali Sat Hanuman Singh immediately rode with the warriors to the Battle of Mudki. This was the first of a series of battles of the Anglo-Sikh war. The gorcharra Akalis attacked the British Bengal regiments, who were encamped and seriously exhausted and dehydrated. The British army thought they had won an untidy encounter battle due to the retreat of the Khalsa army, when in actual fact they had suffered heavy casualties, with about sixty high ranking officers who either perished or were wounded, all of whom must have commanded a considerable amount of men. ${ }^{14}$ Viscount Hardinge in fanciful words stated his reasons of why war was unavoidable at this stage in his intelligence reports, and ended with the clear prophetic proclamation by Currie the Governor General of India to annex the Pun-

\footnotetext{
13 'A Sikh Patriot', “The North-West Frontier”, The Asiatic quarterly review, Woking (England). Oriental University Institute, 1898.

14 Barr 1844: 32-5. In the original reports the top ranks are mentioned as 1 Major General, 13 Lieutenants, 6 Captains, 1 Cornets, and 3 Assistant Surgeons. See my forthcoming book on the history of the Akali Nihangs with Brill (2017) with Mann, Satnam Singh, and Sharanjit Sandhra.
} 
jab to the British territories and confiscate all possessions of Maharaja Dalip Singh. ${ }^{15}$ The British recounted:

The Khalsa Army no longer exists, and the integrity of the Punjab, the kingdom created and ably governed by Runjit Singh, has been destroyed. We are now no longer menaced by a licentious army threatening, at every turn of Durbar politics... (Dowson n.y.: 33).

The Khalsa armies that survived betrayal and the onslaught were disbanded, those who surrendered had their weapons collected and then melted down, and then were paid to return to tend to their fields or follow other occupations.

Shortly after the British understood that their arch enemy, the Afghans, were watching the situation so the same veteran Sikhs were recruited by the British into new Sikh regiments. A large number of Sikhs served in the army of the Lahore Darbar, and many now continued their military service after the annexation of the Punjab with the British. A wise policy of the Governor-General was "the formation of regiments out of the disbanded Khalsa troops, who otherwise might be devising mischief” (Coley 1856: 149). The Sikhs looked transformed with their modern uniform, ornamental weapons on their turbans, and other modified ritualistic objects. Even the previously mentioned farla or miniature battle standard for the turban was upgraded to a version with tassels ${ }^{16}$. Most importantly, it would have a lasting effect, as later on many soldiers would also become active in the Singh Sabha movement (1873) and settle abroad. ${ }^{17}$

According to the concept of 'martial races', the Sikhs were considered as possessing a greater masculine character and being loyal, therefore particularly suitable for military service. The British based their conclusion on their personal experience and reports, accordingly the Sikhs and Gurkhas who did not rebel against the British during the 1857 mutiny were given greater importance. The British utilised the Brahamanic Varna or caste system which classified the martial class as the Kshatriyas (chattri), where the 'lower' castes were forbidden to keep or wear arms. However, they considered all Sikhs regardless of caste as being exceptional warriors even if they were from Mazhabi or Ramdasia castes. Murray writes about the loyalty of the Sikhs in the Mutiny as:

The genius of Sir John Lawrence, the Chief Commissioner of the Punjab, warded off the danger. That eminent man, the saviour of India, issued a proclamation calling on the Sikhs to aid us in our trouble. They came at once in hundreds--nay, thousands--to enlist on our side. Veterans of Runjeet Singh's Khalsa army, the men who had withstood us on equal terms in many sanguinary battles, animated by intense hatred of the Poorbeah sepoy, enrolled themselves in the ranks of the British army, and fought faithfully for us to the end of the war. Their help was our safety; without these soldiers, and the assistance rendered by their chieftains, Delhi could never have been taken; while, on the other hand, had they

15 Ibid., pp. 25, 26. The total of all ranks given was 872 men.

16 See the London Ilustrated News image that follows, where the farla is cearly visable on the second soldier from the right.

17 This transformation was even discussed in some books of the time, but it is too much to include into this current essay. 
risen and cast in their lot with the mutinous sepoys, no power on earth could have saved us from total annihilation (Griffiths 1910: 34-5).

From the above image, it is clear that there were more modifications than Ranjit Singhs' modernisation, like the bayonet replacing the kirpan or talwar. Nevertheless, there was still a transmission of some of the core concepts or chattri ethos of the earlier Sikh soldier. For example, the war slogans found in the secondary Sikh scripture, the Sri Dasam Granth Sahib like the most famous 'Degh-Tegh-Fateh!', which loosely translates to 'Rapid victory to Charity and the Sword'. This slogan is also found on material heritage, namely on Swords, Coins, and Stamps. For the Sikh regiments during the World Wars it became a motto and battle cry. Hookway (1999) in the history of the Mazabhi and Ramdasia Sikh regiments gives the meaning as: "We all wish at all times for our victory in War, which is the victory of our sword, and also our economic prosperity in peace and war - more food, better standard of living and all other riches for our country” (Hookway 1999: 10). Fenech in his detailed analysis of the martyrdom tradition, rightly states that the Gurus saw the destruction of tyranny as the will of God, and the role of a Sikh was to be an instrument of God. After all, the Tenth Guru prepared many of the compositions

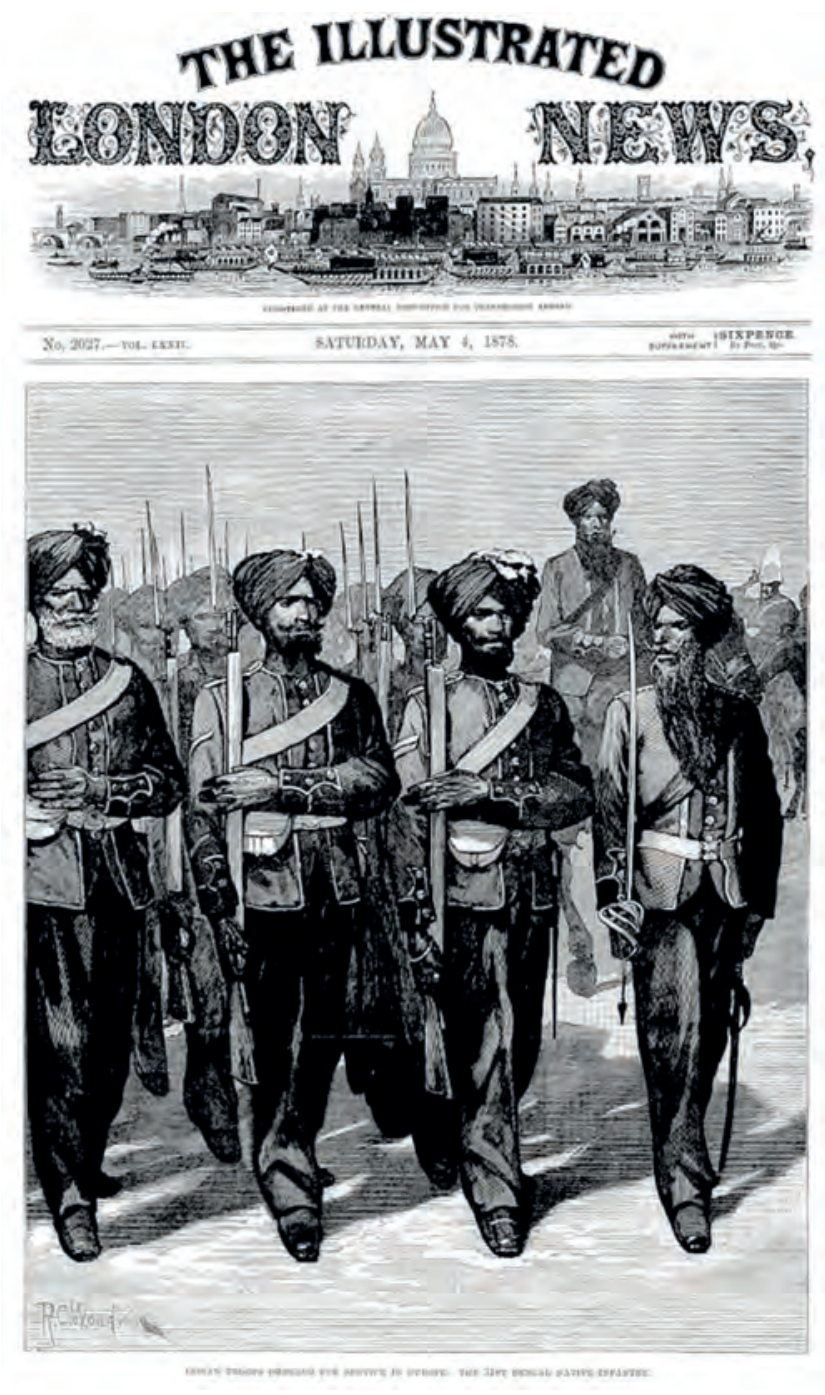

Image 6. How the early British-Sikh Regiments would have looked, circa 1878. The London Illustrated News, May 4, 1878. we find in the Dasam Granth Sahib for that purpose. The Guru has made this point in the Krishanāvtār (the Descent of Krishna) a work which was completed, just weeks before Guru Gobind Singh was about to engage in the battle of Bhangani, vividly described in the Bachitra Nätak (Fenech 2000: 126).

In his fifth chapter, Fenech argues that the Singh Sabha movement promoted the spirit of martyrdom amongst its followers, as it found in the work of writers like Bhai Vir Singh, Bhai Kanh Singh, and others. This naturally served the interest of the British colonialists at that time, he rightly points out that: 


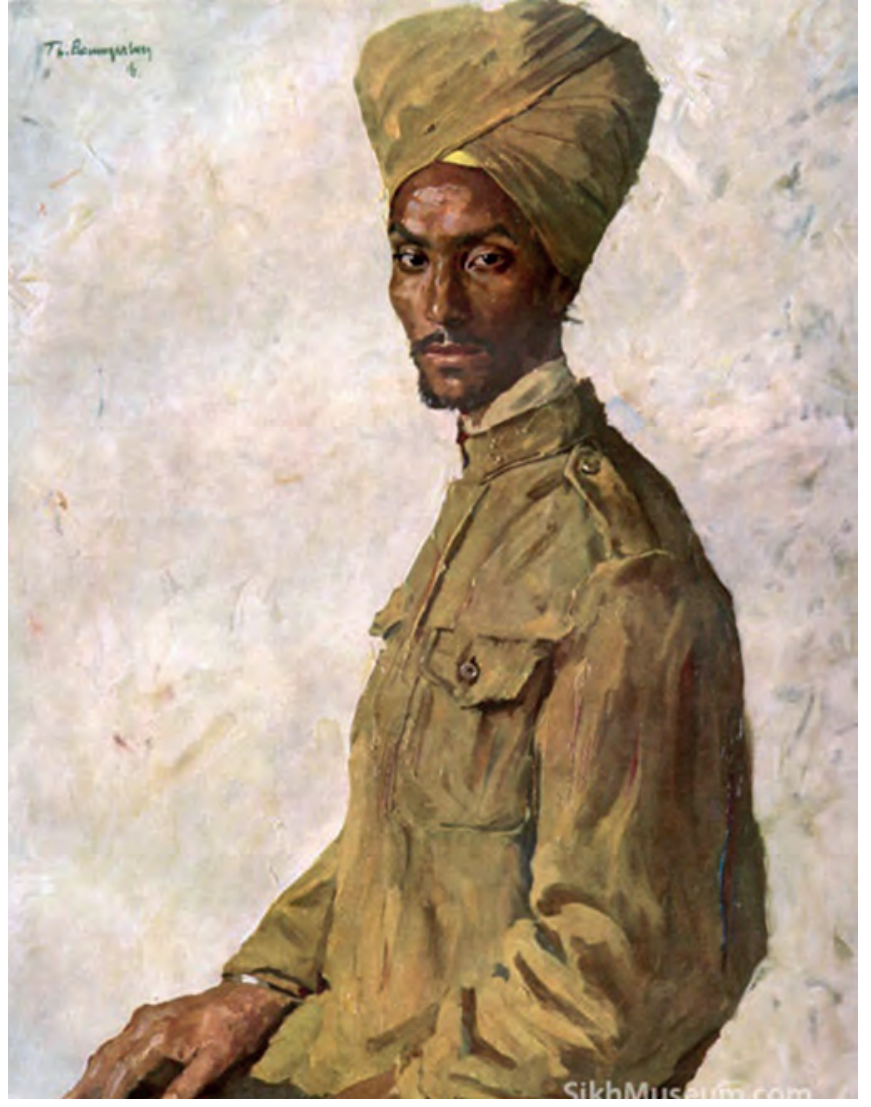

Image 7. 'Sikh vom oberen Indus' by Th. Baumgartner. A Sikh Soldier captured by the Germans in World War I. Printed in Deutschlands Gegner im Weltkriege (Germany's Opponents in the World War) circa 1919.

During the period between 1873 and 1902 (CE), Sikh schools and colleges, often called Khalsa colleges, were established with the support of administrators who saw the value of Sikh loyalty and worth of harnessing the Sikh martial tradition to serve in the British army. This, in turn, promoted Sikh identity, as it became a rule that Sikh soldiers must be kesadhari (Fenech 2000: 146).

This loyalty is exemplified in many letters, particularly one in which a Sikh whose friend Kartar Singh was killed by a shell, when writing back home to his fallen friend's father said,

Do not be dismayed. Your son is a hero who has given his life for his King. He is not dead; he lives for ever. He has gone straight to Paradise, because that is the reward of death in the field of battle in the service of the king. He has in fact achieved in an instant that which saints can only hope to secure after many years of trial.

Fenech also quotes $\underline{d} h a d h \bar{\imath}$ that say that the Sikh soldiers who fell in the world wars were martyrs. In fact, many soldiers would join the Singh Sabha movement, this new self-image was, as Navdeep Mandair argues, was a direct result of colonialism: “This labelling of Sikhism as a martial race thus identified it with the indivisibly masculine signature of colonial culture, an ethnic stereotype whose imprint persists to this day" (Mandair 2005: 40).

An example of Something old - Something new, was the quoit worn in the new regiments on the turban, and the different style of turban. In the British Sikh regiments an ornamental or real chakkar was adorned on the turban. It was seen as the national wea- 


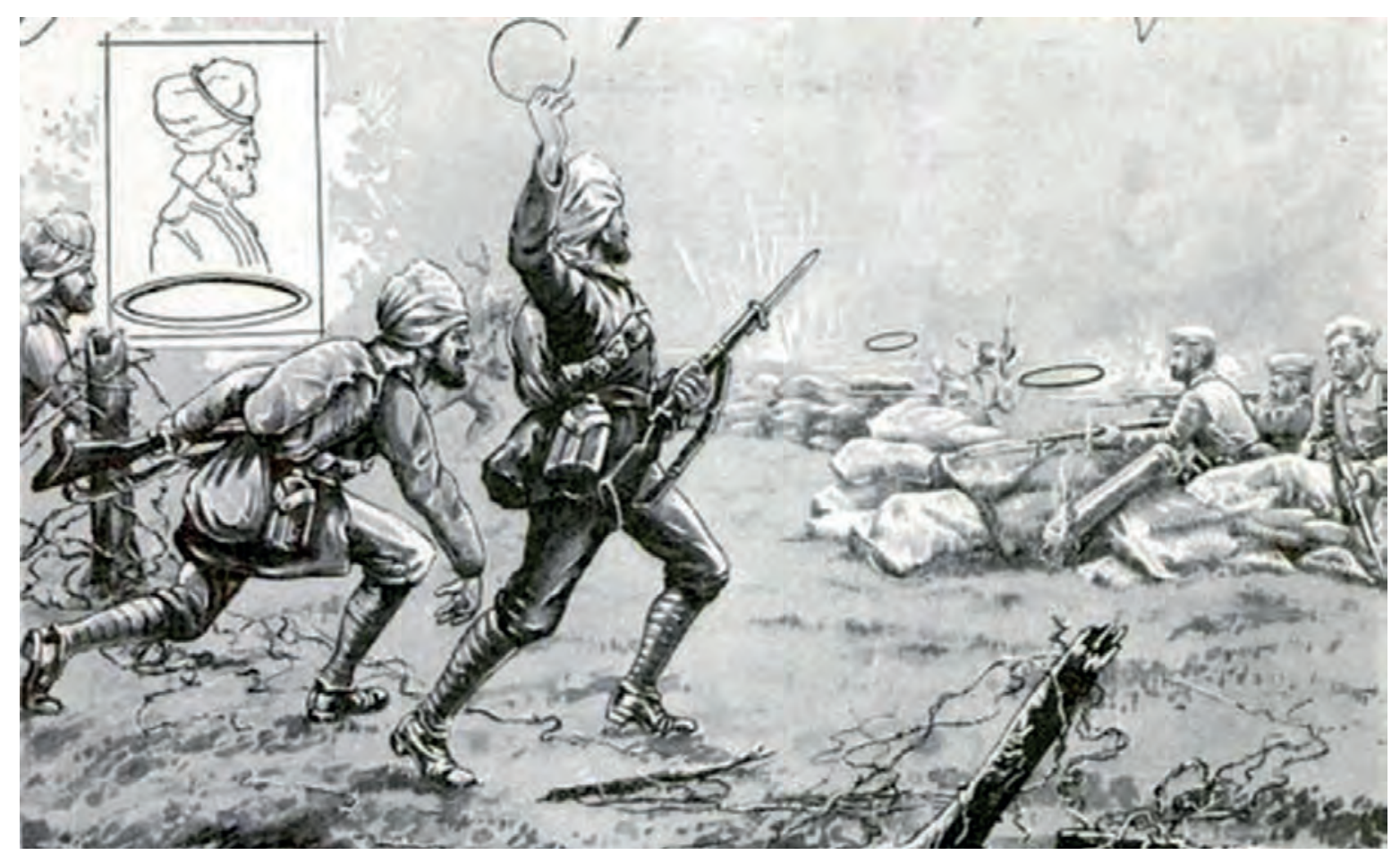

Image 8. The chakra on the battlefield. Popular Mechanics Magazine, The Australian News Co, Chancery Lane, UK, 1919: 593. Further work is required to examine the accounts related to the chakra on the battlefield in World War One.

pon or symbol of the Sikhs. The legend spread that a chakrum could "cut off a man's head in a moment” (Geikie 1882: 18). The Sikhs at that time still took pride in the skill of throwing it. ${ }^{18}$ Unfortunately, many historical weapons were lost due to the Arms Act of India (Smith 1883: 252). Some were sold as scrap metal and melted down, others were sold in auctions, and found their way to museums and private collections in Europe. The use of the chakkar in the newly formed Anglo-Sikh regiments as a military exercise is described as:

They are thrown with great accuracy, and, though not now used for war purposes, the Sikh soldier, in his kusrut or display with his weapons - a kind of assault at arms - will cut in two a gourd elevated on a stick to the height of a man's head, at a distance of fifty or sixty yards (Doré 1886: 175).

The Sri Dasam Granth Sahib has numerous references to this ancient weapon and has a section dedicated to its mythological use. ${ }^{19}$ The relationship of the Khalsa to the chakkar was so strong, that even in World War I the chakkar was launched by the Sikh regiments on the battlefield. In the Popular Mechanics Magazine the use of the 'murderous ring' on the battlefield by the 'Sikh Warriors', and its terrible effects and range were noted, as well as this depiction:

18 “Indian Arms", The Eclectic Magazine of Foreign Literature, Science, and Art, Vol. 44, New York: Leavitt, Trow, \& Co., Aug 1886: 168.

19 For more information see "Chapter 4. The Seed of the Khalsa Raj”, in Kamalroop Singh \& Gurinder Singh Mann 2015. 
The following two photographs show the difference between the tradition and the regiments after modernisation. On the left is a turban extant in the Royal Armouries, and it was acquired from the East India Company in 1851, it has five steel quoits and various Adi Chand or moon emblems that are visible. It is also adorned with various spillikens for use as weapons, with a plume at the top or farla. The photograph on the right is of a
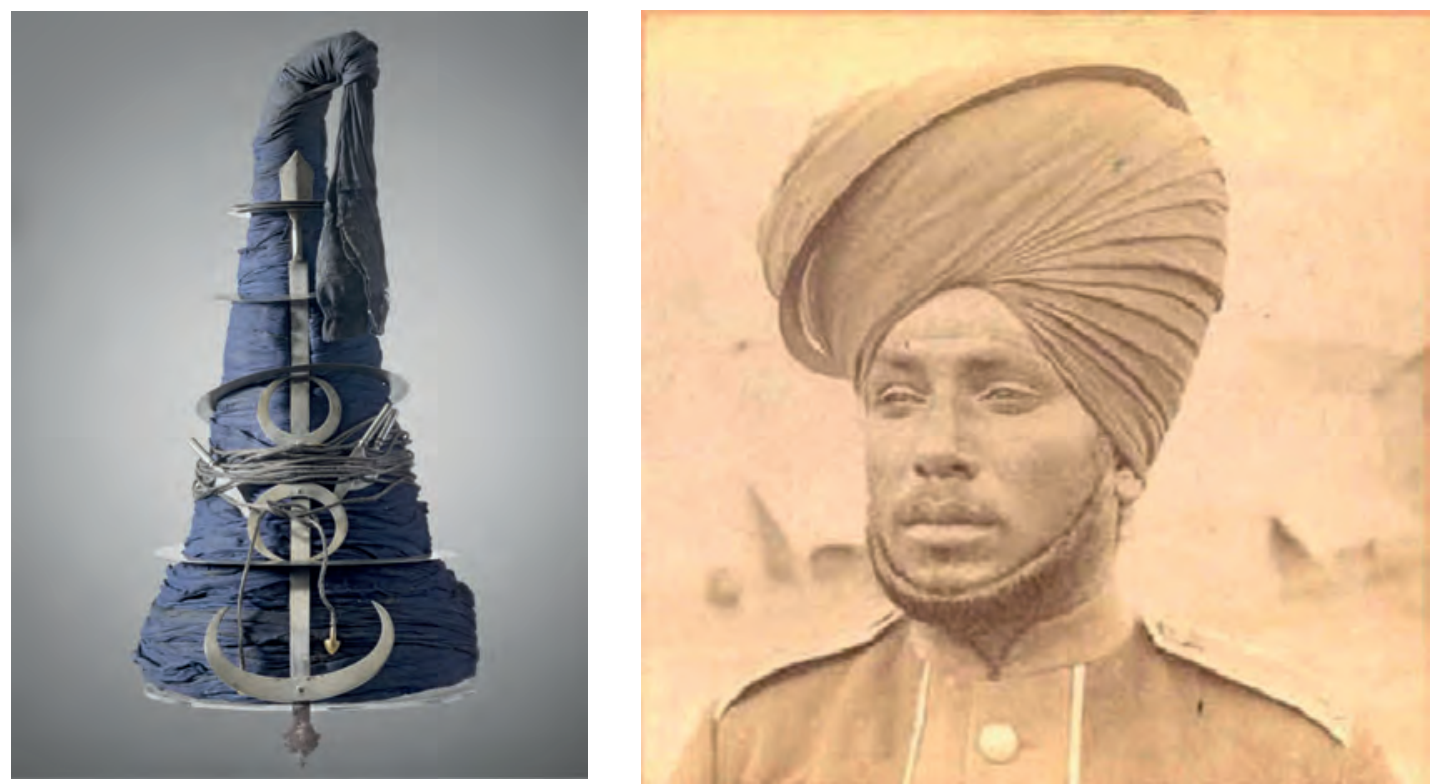

Image 9. Royal Armoury Quoit-Turban. Royal Armouries (26A.60) and an Officer of the 14th Sikhs Infantry, British Indian Troops, Chinese War, China, with the Quoit adorning his turban.

Sikh officer, with the large turban and quoit, with the other novel feature of the British regiments, the neatly tied beard.

The image on the right is from during World War 1, where Sikhs were stationed as part of the Garrison of Tianjin in China and took part in the Siege of Tsingtao. After its capture corruption became rife, so the British also deployed Sikh soldiers as policemen. Later the chakkar would be totally phased out, and an emblem of it for the turban with it was all that was left.

In any army, motivating new soldiers for battle is important, but also giving them solace is equally important, so all religious traditions were encouraged. Therefore, in Sikh regiments the Sikh scripture, the Adi Guru Granth Sahib, was given a central place in all regimental ceremonies. One of the most famous photographs of a Sikh regiment is of the men carrying the scripture to a religious gathering, with the new khaki uniform that became standard issue.

In fact, it was a prerequisite to be initiated as a Khalsa if you were a Sikh, by the rite of Khande-ki-pahul, or initiation of the Double-Edged Sword: 
Many Sikh Indian Army units insisted that all new recruits undertake the ceremony which harked back to the old Sikh army, the Khalsa, which consisted only of those soldiers who had taken the Pahul and embraced all the laws of Sikhism. ${ }^{20}$

It is of great interest that when this took place, the Dasam Granth Sahib would also be ceremonially enthroned with the Adi Guru Granth Sahib, as is clearly visible in this photograph:

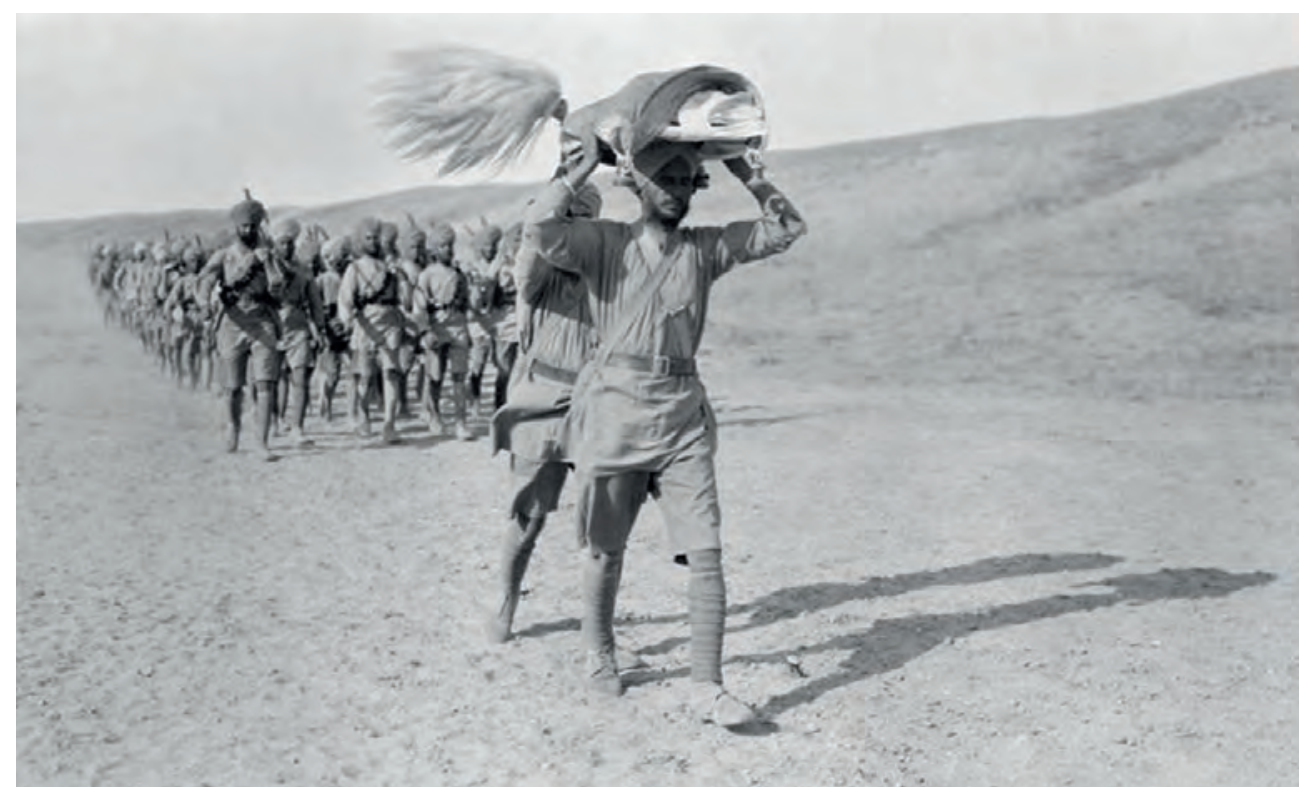

Image 10. Men of the 45th Sikhs (52nd Infantry Brigade, 17th Division). Marching with the Guru Granth Sahib to attend a Diwan (religious service) whilst on campaign in Mesopotamia. Imperial War Museum, Q 24777

Image 11. Sikh religious ceremony for new recruits to the Sikh regiment, 1947. National Army Museum, NAM. 1969-10-590-63. http://www.nam.ac.uk/ online-collection/detail. php?acc $=1969-10-590-63$.

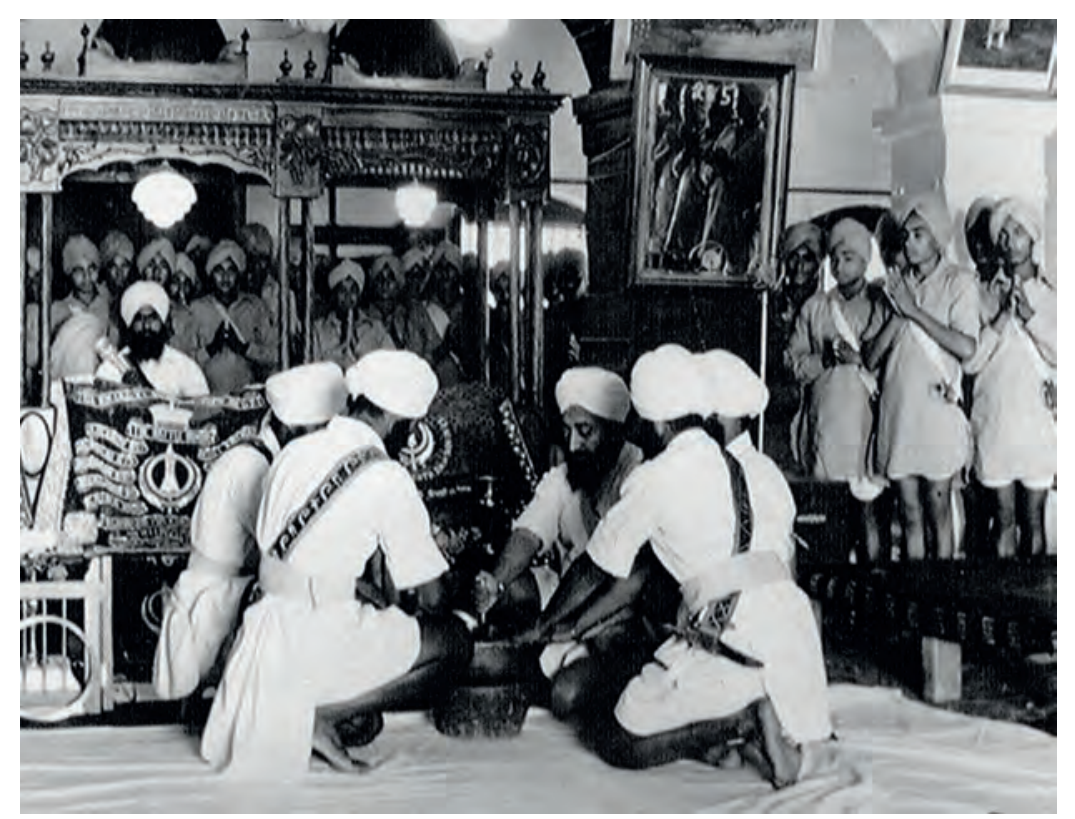

20 http://www.nam.ac.uk/online-collection/detail.php?q=searchType\%3Dsimple\&resultsDisplay=list \&simpleText=Sikh+religious \&pos=2\&total=5\&page $=1 \&$ acc $=1969-10-590-63$ 
Both Granth Sahibs also find a place in the appendix of British commissioned handbook for Indian Army. ${ }^{21}$ Interestingly, as a part of this ceremony, a new line was added which was to swear allegiance with the King of England. Macauliffe noted in his seminal work that:

No superiority of the enemies in number, no shot, no shell, can make his heart quail, since his Amrit (baptism) binds him to fight single-handed against millions. Some people may say that a soldier sells his head for the small wage paid him every month. But the Sikh does not do so: he devotes his head, body, and everything dear to him to preserving the influence of him whom he once makes his master. A Sikh who shows the least sign of reluctance to go, or goes with an expectation of remuneration, when called upon by his benefactor the King-Emperor to fight His Majesty's enemies, no matter how strong they may be, will be condemned by the Gurus (Macauliffe 1909: 24-5).

We have seen an earlier reference in the Prem Sumarag Granth, introduced at the beginning of this article, that requires a Sikh to be loyal to his commander. As we have previously seen in the letters related to Kartar Singh, this loyalty to the King becomes very clear when we read the correspondence letters between the Sikh soldiers and their friends and families. ${ }^{22}$

Image 12. Akali Heera Singh - Head Granthi Or Sikh Priest in Sudan. There were other notable Sikhs in the British Indian army during this period.

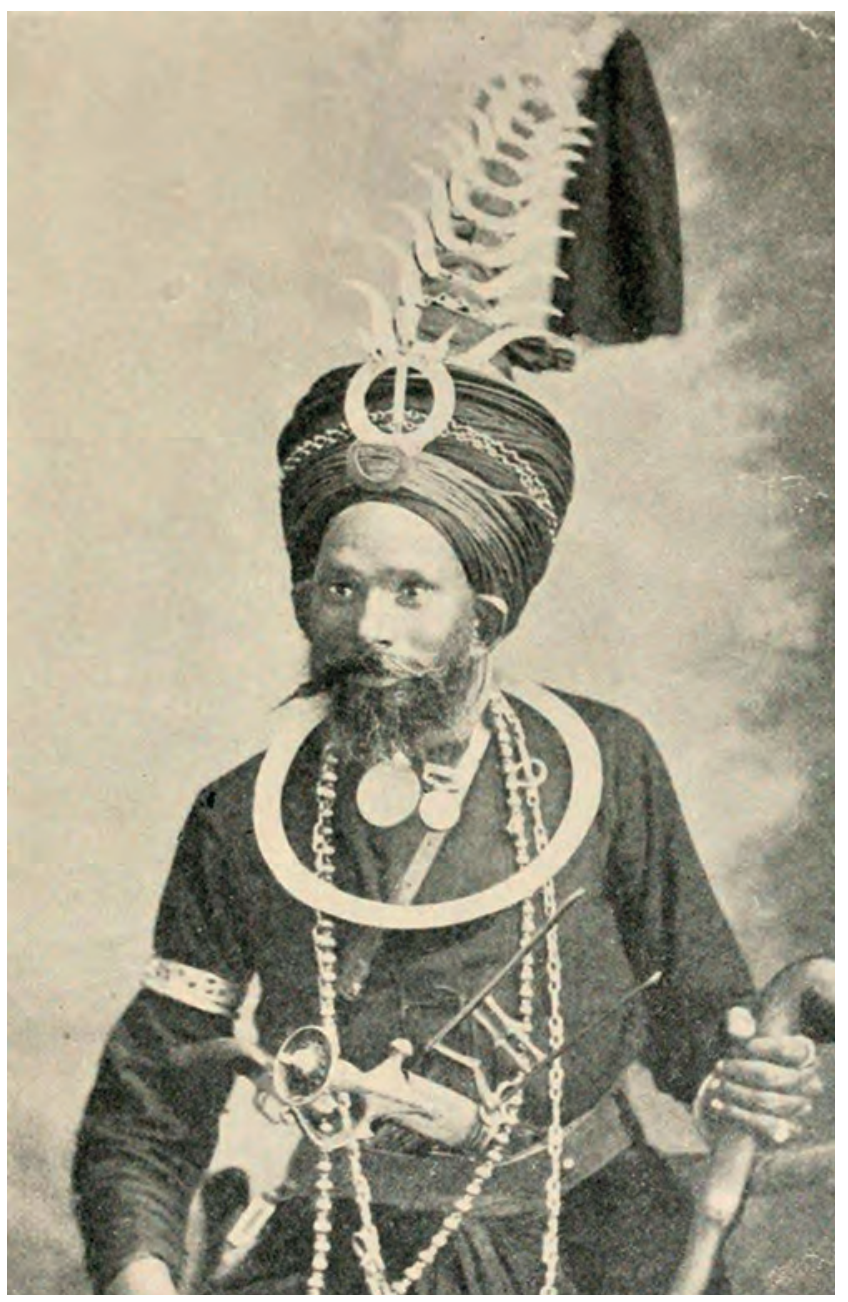

The $5 \mathrm{~K}$ 's formed a part of the dress of these soldiers in the Sikh regiments, and as noted by Sir Winston Churchill, who served with numerous Sikh regiments. He called

21 Barstow 1940: 222-7. He was the Major 2/11th Sikh Regiment (late 15th Ludiana Sikhs).

22 Omissi 1999. 3. An unknown writer to a Jemadar (34th Sikh Pioneers, France), [Urdu], [early January 1915?], Gobind Garh, Punjab. 
for the right for Sikhs to wear these in the House of Commons, due to the sacrifices they made wearing them. ${ }^{23}$

Another striking feature of some of the new regiments was that even Akalis were commissioned as the Sikh Chaplain or Granthi, who is a custodian of the Sikh scriptures. This is no surprise as according to the Martial Races Theory, the Akalis were adept for war and led at the front (MacMunn 1933: 132). At least two Akalis have been uncovered in this role, and we are sure there are more. One famous Granthi was Akali Baba Heera Singh, who served not only as a Granthi but also on the battlefield. He served in numerous places including in the Sudan and was photographed numerous times.

The following report was written by a correspondent of the 'The South Australian Advertiser' during Akali Heera Singh's visit to the Calcutta International Exhibition on 19 February 1884:

His name is Heera Singh, and he is an Akali Nihang, or follower of Guru Gobind Singh, the tenth and last Guru of the Sikhs. He stands about 6 feet 3 inches in height in his slippers, and as he wears a headdress over 2 feet in height his appearance is sufficiently imposing. This headdress is called a Guja, and is in the form of a conical puggaree, bound round with massive steel and silver chains. From the crown it runs up to a point, the upper portion being ornamented with nine crescents of polished steel, very sharp at the edges, and capable of being used as weapons. The peak of the headdress terminates in a steel spearhead, so that a charge from one of these gentlemen, a la billy goat, would probably interfere considerably with the digestion of his adversary if delivered well below the belt. Around the top of the hat are carried six quoits, or flat steel rings about 9 inches in diameter, very sharp on the outer edge, which, I am informed, are used by the Sikhs as weapons, being slung from the finger with such force as to take off a man's head at a considerable distance. Round the neck a still larger quoit is carried. The other arms carried by Heera Singh were a tulwar or curved sword, a Colt's revolver, a dagger, and a katar - an extraordinary weapon for thrusting, which has the property of opening two blades after the fashion of a pair of tailor's shears when the thrust has been delivered. Altogether our Sikh friend would be rather a formidable enemy, and he walks the exhibition with an air of contemptuous superiority which plainly declares that he knows it. Heera was brought to Calcutta by Mr. E. Nicholl. He has done good service for the British Government in many frontier fights. He carries the Jowaki medal, and is in receipt of a pension of four rupees per day, having served in the 6th Punjaub force for nineteen years. [sic]

The letters copied by British military censors, also reveal the experiences of many Indian soldiers, which have recently been digitilised by 'Europeana 1914-1918' and the British Library. ${ }^{24}$ This collection also reveals the concerns of the censors' with their summaries of the letters. The letters show the grim determination of many of the soldiers, but also depict the horror of war. The soldiers refer to their own scriptures where good is victori-

23 In his speech in the British Parliament, "At that time because of our own critical position, we did not compel them to wear steel helmets; we should now earn their appreciation by respecting their religious feelings and symbols and therefore happily exempt them from the obligation of wearing steel helmets".

24 http://www.europeana1914-1918.eu/en 
ous against evil: “The mud is up to a man's knees, and the trenches are full of water up to a depth of about 2 feet. As in the history of Ala [a great Sikh warrior]”. A letter from Punjab to France from 19 January 1916 states:

We are all thinking of you and this is our prayer in the presence of the Almighty - that the Guru may bring you back with victory. You must know that you are very fortunate in that you have got a chance to defend your country and to serve the British government. You will remember that the British rule was foretold by our true leader Tegh Bahadur, the ninth Guru. It was established in India only for the protection and help of us Sikhs. It was on the voice of the Guru that the Eternal sent the English here. The blessings which this rule has brought to India is not concealed from you. The rise of the Sikhs is due solely to this power. But for this, the poor Sikhs would have brought their unhappy existence to an end in some crows' pond [sic]. I shall be very pleased to hear of your valorous deeds. You are a brave soldier. Now it is time to display your manhood. Now is the time for loyalty. You are a true Sikh. By the Guru's order you must remember the promise of the Almighty, who said:

Recognise the hero in him who fights for his faith; Though cut to pieces he will not quit his ground.

[sura so pahichaniai jolarai dheen ke heth. puraja puraja kat marai kabihu na chhadai kheth .2.2. Bhagat Kabir, Adi Sri Guru Granth Sahib, p. 1105.]

This for Sikhs is a religious war, because the war is directed against the [British] rule which our Guru established. ${ }^{25}$

A Sikh soldier, Indar Singh, fighting on the Somme in September 1916, wrote home:

Don’t be grieved at my death, because I shall die arms in hand, wearing the warrior's clothes. This is the most happy death that anyone can die. ${ }^{26}$

This religious sombreness is repeated time and time again: 'Death is ruled by time and both by battle, and if it be death, then welcome death.' Which is a verse spoken by the Tenth Guru in the Dasam Granth Sahib, “At hì ran mai tab jūjh maron - when the last moment of life comes may I die fighting” (Dasam Granth Sahib, verse 231). A sepoy of the 47th Sikhs (Sikh) writing from Brighton hospital to his friend in India on 14th December 1915 recollects that:

Chur Singh has suffered martyrdom in the war. The 47th Sikhs were charging. [The] sahib said 'Chur Singh, you are not a Sikh of Guru Govind Singh, [you who in fear remain in the trench!' Chur Singh was very angry. Chur Singh gave the order for his company to charge. He drew out his sword and went forward. A bullet came from the enemy and hit him in the mouth. So did our brother Chur Singh become a martyr. No other man was like Jemadar Chur Singh.

25 Omissi 1999: 222 - From Punjab to France -19th Jan. 1916.

26 Omissi 1999: 239. [Letter No. 401] Jemadar Indar Singh (Sikh) to Chattar Singh (Ludiana Disst, Punjab), FPO.42, Urdu, France, 15th September, 1916. 
While another refers to drinking tea as drinking amrit, or spiritual ambrosia taken during the aforementioned intiation rite. The rural life of Punjab is also portrayed 'As a man climbs a plum tree and shakes down the plums [so that] they fall and lie in heaps, so are men here fallen ...' The censor notes the religious fervour of many of the soldiers, where he makes note that, 'extracts from the Granth... and the like would give more pleasure than a great deal of sweetmeats and tobacco. ${ }^{27}$

\section{Neuve Chapelle}

The Indian army at this time was drawn mainly from Jatts or farmers, recruited from the north of India partly on account of the 'martial races' theory of the British which suggested that some races or castes were inherently more warlike than others (MacMunn 1933). Most Indian soldiers in France were Punjabi Jatt who were mainly Muslims and Sikhs. There is also evidence that many were forced to conscript (see, Omissi, 1999). As noted earlier the Sikh regiments served in Europe, and an obvious and famous example was the Battle of Neuve Chapelle in France. An excerpt of the arrival of the Sikh regiments in the First World War from a collection of The Guardian reports their contempt of death:

The day after, we heard that during the night one of the Sikh regiment had had to recapture the trench, which the Germans had taken by surprise, and that their bayonet charge was so tremendous that the enemy did not dare counter-attack. Almost immediately after that feat an order came not to allow the Indians uselessly to expose their lives by walking out of the trenches. The fact was that, in order to show their contempt for death, some Sikhs had refused to hide themselves in the trenches and had immediately drawn a fierce fire on their regiment. Fortunately, they did not insist on playing that sort of game; otherwise the Indian Army Corps would have disappeared in one week’s time out of sheer bravery. [... $]^{28}$

The bravery of the Sikh regiments was celebrated in art and written about in magazines of the period. See the text and painting below which describes what transpired in this particular battle:

A 'Black Maria' fell quite near a sapper while he was lying on the ground and steadily firing on the advancing foe. It did not hurt him, but dug a hole six feet deep at his side. The sapper - a Sikh, I believe - waited until the smoke had gone, and then jumped into the hole. He soon found that the position was a comfortable one, and started firing from the cover the Germans had dug for him; according to officers who were standing by, he managed to kill some fifteen or twenty Germans by himself, and would have remained there for ever if he had not been eventually ordered to retreat. He was warmly congratulated afterwards, but did not appear to think he had done anything remarkable.

One of the most famous stories of Neuve Chapelle is the centennial story of Manta Singh's, who courageously sacrificed his life to save his commanding officer. He was born near Jalandhar in 1870, and went onto join the 15th Ludhiana Sikhs, and was sent

27 IOR/L/MIL/5/825/6, Sep 1915-Oct 1915, IOR/L/MIL/5/826/2, Jan 1916-Mar 1916,

28 'When the Indians Arrived,' The Guardian, 12 November 1914. 


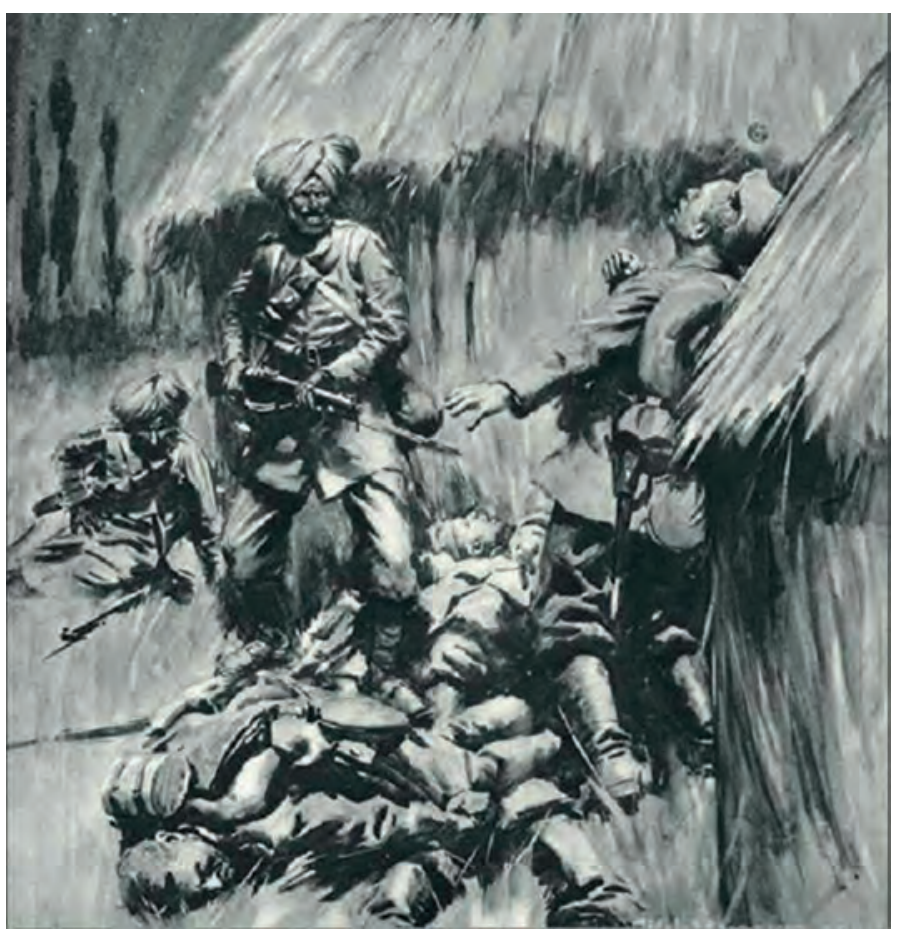

Image 13. "Saving a Wounded Comrade: Sikh Sergeant Keeps German Patrol at Bay", circa 1914. From The Great War: Part 94, The Standard History of AllEurope Conflict, Week Ending June 3, 1916.

to France in 1914. In March 1915, during the Battle of Neuve Chapelle, he rescued Captain Henderson, who was seriously wounded, by pushing him to safety in a wheelbarrow, but was then severely injured himself. He was admitted to the Kitchener Indian Hospital in Brighton, but his wounds had become infected and he died a few weeks later. Manta Singh and Henderson, became close friends while he was undergoing treatment, and after his death, Henderson ensured that Manta Singh's son was taken care of, and encouraged him to join the Sikh Regiment. ${ }^{29}$

\section{Gallipoli}

When Lord Kitchner, the Secretary of State for War, received an appeal on 2 January 1915, he also realised that the terrain greatly favoured the Turks, who were well dug-in. To meet this challenge he called upon the 14th Sikhs as a part of his expeditionary force. Sir Hamilton wrote to the Commander-in-Chief in India about the great Sikh sacrifice in this battle:

In spite of the tremendous losses there was not a sign of wavering all day. Not an inch of ground was given up and not a single straggler came back. The ends of the enemy's trenches were found to be blocked with the bodies of Sikhs and of the enemy who died fighting at close quarters, and the glacis slope was thickly dotted with the bodies of these fine soldiers all lying on their faces as they fell in their steady advance on the enemy. The history of Sikhs affords many instances of their value as soldiers, but it may be safely asserted that nothing finer than the grim valour and steady discipline displayed by them on the 4th June has ever been done by soldiers of the Khalsa.

29 In the the Second World War, both Manta Singh's and Henderson's sons served together, in France, Italy and North Africa. Both of them have now passed away, but their sons, Jaimal and Ian remain in contact. 
Sikhs fought alongside the Anzacs at Gallipoli with the 14th Sikh Regiment suffering possibly the highest casualty rate of any force during the Gallipoli campaign, with only four survivors. ${ }^{30} 379$ Sikh officers died on the 4 June 1915 , which virtually wiped out the 14th Sikh Regiment. These Sikhs were mostly from India, but there were also ten Sikhs from Australia who served as part of the Australian Imperial Force.

Image 14. Wounded

Sikhs at Brighton

Pavillion. WW1, postcard, circa 1916

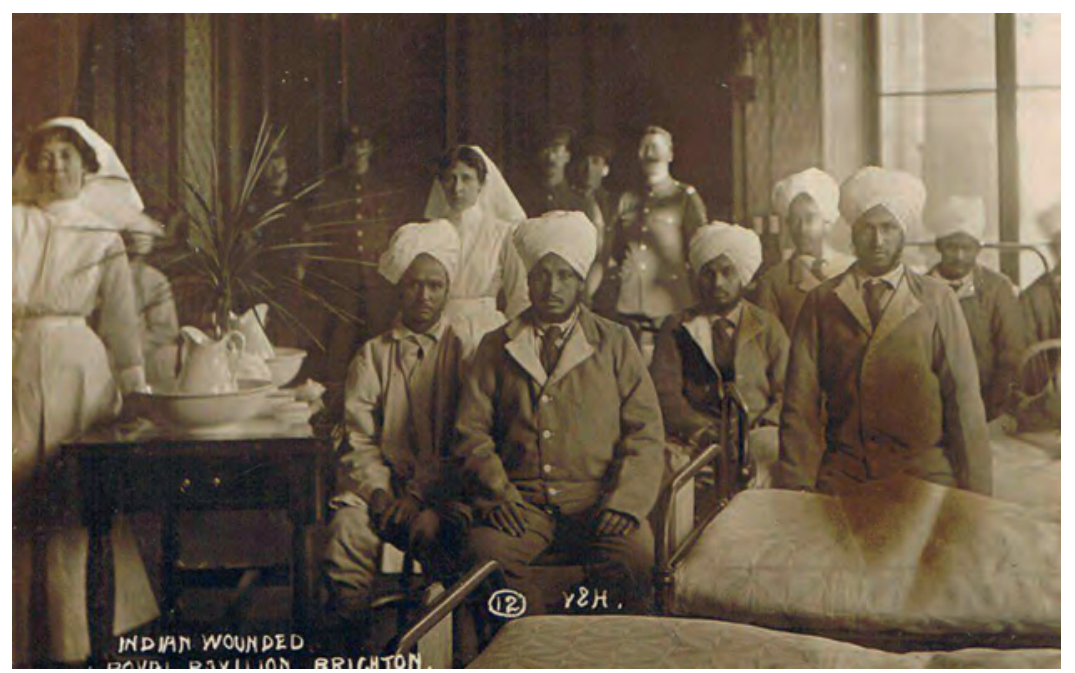

Image 15. This photo is an Indian Regiment Memorial, including the Sikhs, from Haifa, Israel. Photograph courtesy of Manbir Singh Banwait, 2015.

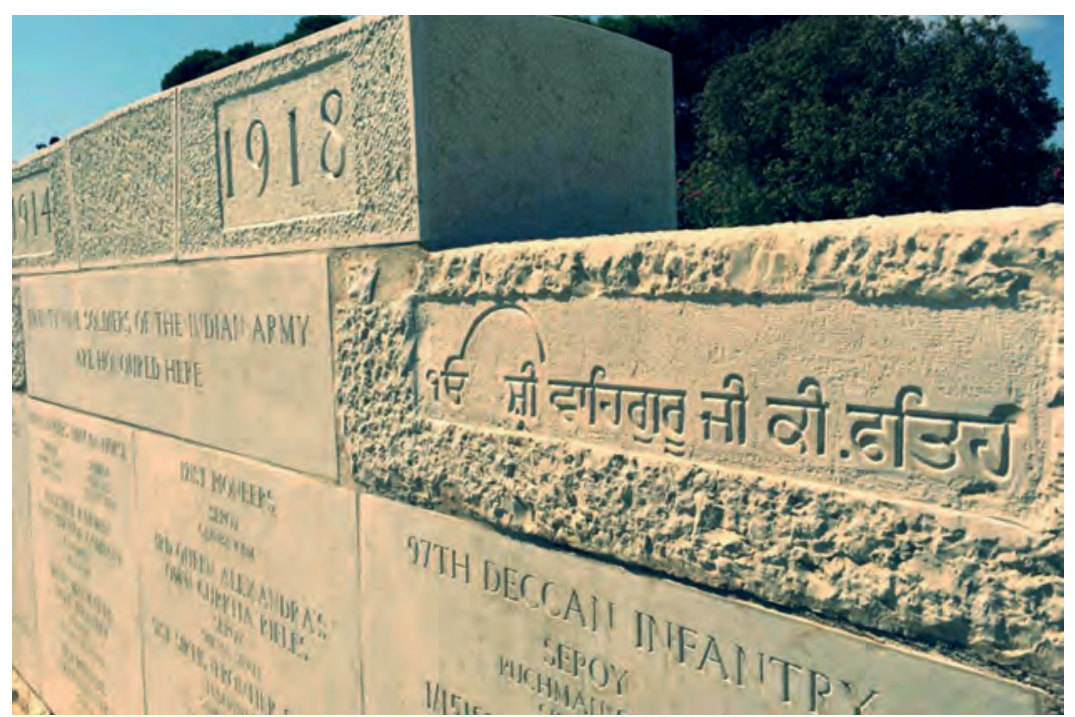

The wedding party of Sikhs proved they could play the game of love, with around 83,000 Sikhs giving their heads on the palm of their hand. Taking into battle something old and something new, they embraced death, and the wounded Sikhs - over 100,000, were sent to hospitals like the one at Brighton Pavilion, which had been turned into a hospital for Indian soldiers. A wounded Sikh writes to his father:

Tell my mother not to go wandering madly because her son, my brother, is dead. To be born and to die is God's order. Some day we must die, sooner or later, and if I die here, who will remember me? It is a fine thing to die far from home. A saint said this, and, as he was a good man, it must be true. ${ }^{31}$

30 One survivor was Lance Naik Bhola Singh of the 14th Sikhs, who was wounded in Gallipoli.

31 [Gurmukhi], Brighton Hospital, 18th January 1915 


\section{Conclusion}

The Sikh tradition laid out by the Gurus, particularly the martial or chattrī ideals of selfsacrifice for the greater good, were utilised by Maharaja Ranjit Singh and his European Generals to have an army on par with the British. They created modern Sikh Regiments to prepare against the threat of a British invasion. He utilised the Akalis for his own purposes, which also kept their numbers in check. This was the beginning of "something old and something new". After the annexation of Punjab, the Sikhs later joined the British Sikh Regiments. We can clearly see the influences from them being recruited into the British Army. Firstly the quoit, which was a usable weapon, was reduced to a an ornamental role to represent them as a people. The blue colour was changed to khaki, and the kirpan to a bayonet instead. The flowing beard was now tied up due to the needs of modern warfare. The British also utilised the martial Akalis in their regiments to fulfil the religious roles of the new Sikh Regiments.

By studying Sikh scriptures and by analysing their behaviour particularly in the mutiny, the British understood the psychology of the Sikhs well. The 'Martial races' became a concern after an enquiry, the British realised that Sikhs had a firm resolve to their duty to their commanders. Furthermore, those that survived the marriage party of war or were 'martyred', increased the izzat or honour of their family and would have been immortalised as heroes. This led to a tremendous sacrifice by the Sikhs, who to this day are widely known for their martial prowess in World War I and II, where they received many Victoria Crosses even though the Sikhs were very small in number.

\section{Bibliography}

Affeife, Giani Nihal Singh (1959), Two Shining stars (The unique martyrdom). Delhi: Afifzada.

Abuja, R.L. (1984), "Philosophy of martyrdom”. Panchbati Sandesh, Vol. 6, No. 4.

Abuja, R.L. (1978), "Politics of martyrdom”, Journal of Sikh Studies, Vol., No.1.

Adi Guru Granth Sahib.

Amar Singh (1996), "Martyrdom that re-vitalized Dharma”, Sikh Review, Vol. 44, No.12.

Anand, Mulk Raj (1986), “Martyrdom of innocents,” Spokesman Weekly, Vol. 36, No.16.

Balkar Singh (2000), "Martyrdom: A continuing feature in Sikhism”, Journal of Sikh Studies, Vol. 24, No. 2.

Bajwa, K. S. (2003), "The first martyr of Gurdwara reform movement: Bhai Hazara Singh", Punjab History Conference Proceedings (35th session).

Barr, W. (1844), Journal of a march from Delhi to Peshâwur: And from thence to Câbul, Vol. 2. London: Madden \& Co.

Barstow, Major A. E. (1899), A handbook for the Indian Army: Sikhs. Calcutta. Bhag Singh (1987), “A Saga of the Sikh courage”, Sikh Review, Vol. 35, No. 405.

Bhatia, H. S. and S. R. Bakshi, Eds. (2000), National movement and the Sikhs: The martyrdom tradition. Deep \& Deep Publications. 
Bhogal, Balbinder Singh (2007), “Text as sword: Sikh religious violence taken for wonder” in J. Hinnells \& R. King (eds.), Religion and violence in South Asia: Theory, precept and practice. London \& New York: Routledge.

Browne, C. (1861), The Punjab and Delhi in 1857: being a narrative of the measures by which the Punjab was saved and Delhi recovered during the Indian Mutiny, Vol. 1. Edinburgh \& London: Blackwood.

Bosworth Smith, R. (1883), The life of Lord Lawrence, 1849-1852. London: Smith, Elder \& Co.

Cheema, Baljinder Singh (1987), “Concept of martyrdom in Sikhism”, Sachkhand Petra, Vol.13, No.5.

Concise List of Sikh Martyrs (n.y), Amritsar: S.S. Missionary College.

Cunningham, J. (1846), A history of the Sikhs. London: J. Murray.

Darshan Singh (2000), “Nature and tradition of martyrdom in Sikh religion”, Journal of Religious Studies, Vol.31, No,1-2.

Das Gupta, R.K. (1987), “Least we forget those patriotic Sikhs”, Aryan Heritage, Vol.4, No.36.

Dasam Granth Sahib.

Dhillon, Ravinder Singh (1999), “Sahidi tradition in Sikhism”, Sikh Review, Vol.47, No.2.

Dowson, J. (n.y.), A classical dictionary of Hindu mythology and religion, geography, history, and literature; Selections from the Koran; Modern India and the Indians; Metrical translations from Sanskrit writers, Original work published pre-1945, year unknown.

Doré, Gustave (1886), The Electic Magazine.

Dorna, Walter A., and Gucciardib, Stephen (2011), "The sword and the turban: Armed force In Sikh thought”, Journal of Military Ethics, Vol. 10, Issue. 1.

Fenech, Louis E. (1997), "Martyrdom and the Sikh tradition”, Journal of the American Oriental Society, Vol.17, No.4.

Fenech, Louis E. (2000), Martyrdom in the Sikh tradition: Playing the 'game of love', Delhi: Oxford University Press.

Fenech, Louis E. (2001), "Martyrdom and the execution of Guru Arjan in early Sikh sources”, Journal of the American Oriental Society, Vol. 121, No. 1.

Fenech, Louis E. (2002), “Contested nationalism: Negotiated terrains: The way Sikhs remember Udham Singh 'Shahid‘ 0899-1940”, Modern Asian Studies, Vol. 36, No.4.

Francklin, W. (1805), Military memoirs of Mr. George Thomas.

Geikie, John Cunningham, Samson and Eli (1882), Hours with the Bible, or, the Scriptures in the light of modern knowledge. New York: Hurst \& Company.

Gopal Singh and Darshan Singh Pheruman (1994), "The first martyr of Sikh homeland", in Politics of Sikh homeland, 1940-1990. Delhi: Ajanta Publications.

Gulcharan Singh (1970), "Young martyrs”, Sikh Review, Vol.18, No.189.

Hookway, J. (1999), M \& R A regimental history of the Sikh Light Infantry 1941-1947. Beckington, Bath.

Humbly, W. (1854), Journal of a cavalry officer: Including the memorable Sikh campaign of 1845-46. London: Longman. 
"Indian Arms" (1886), The Eclectic Magazine of Foreign Literature, Science, and Art, Vol. 44.

Kamalroop Singh and Gurinder Singh Mann (2015), The Granth of Guru Gobind Singh: Essays, lectures and translations. New Delhi: Oxford University Press.

Lafont, J. M. (1986), French administrators of Maharaja Ranjit Singh. Delhi: National Book Shop.

Macauliffe, M. A. (1909), The Sikh religion, Vol. 1. Oxford: Clarendon.

MacMunn, G. (1933), The martial races Of India. London: Marston.

Malcolm, J. (1812), Sketch of the Sikhs. London: J. Murray.

Mandair, N. (2005), "(En)gendered Sikhism: The iconolatry of manliness in the making of Sikh identity”, in Sikh formations: Religion, culture, theory, Vol. 1, No. 1.

Nijhawan, M. (2006), Dhadi Darbar. Delhi: Oxford University Press.

Omissi, David (1999), Indian voices of the Great War: Soldiers'letters, 1914-18. New York: St. Martins.

Omissi D. (1991), “'Martial races’: Ethnicity and security in colonial India 1858-1939”, War \& Society, Volume 9, Issue 1: 1-27.

Omissi, D. (2012), "Sikh soldiers in Europe during the Second World War, 1914-1918”, in Knut A. Jacobsen and Kristina Myrvold, Sikhs across borders: Transnational practices of European Sikhs. London: Bloomsbury.

Prinsep, H. (1834), Origin of the Sikh power in the Punjab and political life of Muha-raja Runjeet Singh. Calcutta: Huttman.

Roy, K. (2001), “The construction of regiments in the Indian Army: 1859-1913”, War In History, Vol. 8, No. 2: 127-148.

Sidhu, A.S. (2013), The First Anglo-Sikh War. The Hill: Amberley.

Skinner, J. (1825), “The Sikh community”, From the Persian, Kitab-ī Tashrīhu'l Aqwām (History of the origin and distinguishing marks of the different communities of India), transl. Shireen Moosvi.

Streets, H. (2004), Martial races: The military, race and masculinity in British imperial culture, 1857-1914. Manchester University Press.

The Australian News Co (1919), Popular Mechanics Magazine.

The London Illustrated News (1878). 